International Journal of Environment, Agriculture and Biotechnology
Vol-6, Issue-4; Jul-Aug, 2021
J Journal Home Page Available: https://ijeab.com/
Journal DOI: $10.22161 /$ ijeab

Article

Peer-Reviewed Journal

\title{
Assessment of the contribution of home garden and its component on household income and home garden income of disadvantaged groups (DAGs) in Jhapa district of Nepal
}

\author{
Benu Prasad Prasai ${ }^{1 *}$, Durga Devkota ${ }^{2}$, Krishna Kumar Pant $^{2}$ and Ram Hari Timilsina ${ }^{2}$
}

${ }^{1}$ Seed Quality Control Center, Ministry of Agriculture and Livestock Development, Nepal

${ }^{2}$ Agriculture and Forestry University, Rampur, Chitwan, Nepal

Received: 03 Jun 2021; Received in revised form: 05 Jul 2021; Accepted: 12 Jul 2021; Available online: 24 Jul 2021

(C)2021 The Author(s). Published by Infogain Publication. This is an open access article under the CC BY license

(https://creativecommons.org/licenses/by/4.0/).

\begin{abstract}
Nepalese agriculture is subsistence based and furthermore, farms are getting smaller and subsistence farm families are on the rise.Home garden, traditional land use system around a homestead, where several species of plants are grown along with livestock. Home garden provides fruits and vegetables to the household with direct access to important nutrients that may not be readily available or within their economic reach. A study was conducted in three VDCs of Jhapa namely; Dharampur, Dangibari and Dhaijan to assess the contribution of home garden to total household income. The study reveled that among the three VDCs total own land, total plant species, were found significant and others were not significant. Mean of total plant species was found 42 and significant $(P=0.5)$ among the VDCs. The home garden contribution on annual household income was $19.23 \%$ and livestock component was identified as most profitable component as it contributes $50.92 \%$ of home garden incomes followed by vegetable component (25.02\%). The total household income was found higher in home garden practitioner compared to the non-practitioner household but it was not statistically significant. It was found that the mean annual income from home garden was NRs 37697.24 in practitioner household and significant $(P=0.05)$. Among the home garden components the annual income was found highest in livestock component (NRs. 19197.77) followed by vegetable component (NRs. 9434.44). The annual income from home garden components such as vegetables, fruits and livestock components were found significant and higher in practitioner household whereas annual income from poultry and other component was not significant and higher in non-practitioner household The research suggested to promote home garden in order to increase the food security situation and income of the farmers.
\end{abstract}

Keywords-Agriculture, Home Garden, Income, Practitioner, Food security.

\section{INTRODUCTION}

Agriculture is the largest economic sector employing 65.7 percent of economically active population and sharing 35.1 percent in the GDP (MoAD, 2013).Nepalese agriculture is subsistence based and furthermore, farms are getting smaller and subsistence farm families are on the rise. Three types of interventions are commonly employed to improve micronutrient status, namely: capsule and tablet supplementation, fortification of commonly consumed foods, and diet diversification. Diet diversification is arguably the most sustainable and affordable strategy to improve nutrition for the majority of the population particularly the poor. For poor households, vegetables and fruits are often the only source of micronutrients in the family diet. Home garden, traditional land use system around a homestead, where several species of plants are grown along with livestock and maintained by household members and their products are primarily intended for the family consumption (HKI, 2001; Mictchell and Hanstad, 2003). Home garden provides fruits and vegetables to the household with direct access to important nutrients that 
may not be readily available or within their economic reach. Home garden is one of the most complex and diverse agro-ecosystems worldwide. Home garden systems have existed for millennia (Kumar and Nair, 2004; Soemarwoto and Conway, 1992) in many tropical regions, where they played an important role towards the development of early agriculture and domestication of crops and fruit trees, a still ongoing process (Kimber, 1978; Miller and Nair, 2006; Ninez, 1987; Smith, 1996).

Therefore, home gardening would be a good means to improve household food security. Equally important, home gardening has been shown to be a source of additional income, because the household can sell a portion of the garden's produce. The home garden, literally known in Nepali as GharBagaincha, refers to the traditional land use system around a homestead, where several species of plants are grown along with livestock and maintained by household members and their products are primarily intended for the family consumption (Shrestha et al., 2002). In Nepal, $72 \%$ of households have home gardens of an area $2-11 \%$ of the total land holdings (Gautam et al., 2004). The current research highlights the contribution of home garden to total household economy.
Home garden approach is a group based inclusive intervention which intends to contribute household food security and family nutrition through homestead agrobiodiversity management. The study was conducted in three VDCs of Jhapa district to analyze the effectiveness of home garden approach for household food security and socio-economic empowerment of disadvantaged people. Both descriptive and analytical survey design was used for this study. Altogether 120 respondents (40 respondents from each VDC) were randomly chosen. Descriptive statistics, one way ANOVA test, chi-square tests were employed to address the objectives set forth.

\section{RESULTS AND DISCUSSION}

\section{Distribution of home garden practitioners by family type}

Home garden practitioners were classified on the basis of the family type such as joint and nuclear. The study revealed that majority of the household was under joint family system (55.6\%). Among the three VDCs, Dhaijan had the highest percentage of joint family (23.3\%) followed by Dharampur (12.2\%). Nuclear family type was found highest in Dangibari VDC (21.1\%) followed by Dharampur VDC (13.3\%). The distribution of home garden practitioners by family type is statistically significant $(\mathrm{p}=0.029)$ across the VDCs (Table 1).

\section{MATERIALS AND METHODS}

Table 1. Distribution of the home garden practitioners by family type

\begin{tabular}{lcccc}
\hline & & Name of VDCs & & Total \\
\cline { 2 - 5 } Type of family & Dharampur & Dangibari & Dhaijan & $(\mathrm{N}=90)$ \\
& $(\mathrm{n}=30)$ & $(\mathrm{n}=30)$ & $21(23.3)$ & $50(55.6)$ \\
\hline Joint & $18(20.0)$ & $11(12.2)$ & $9(10.0)$ & $40(44.4)$ \\
Nuclear & $12(13.3)$ & $19(21.1)$ & $30(33.3)$ & $90(100.0)$ \\
\hline Total & $30(33.3)$ & $30(33.3)$ &
\end{tabular}

Source: Field survey, 2013

Figures in parenthesis indicate percentage

$\chi 2$ - value 7.110 at $2 \mathrm{df} \quad(\mathrm{p}=0.029)$

\section{Land holding characteristics}

The mean size of land holdings of the home garden practitioners was higher in Dangibari (23.61 kattha) followed by Dharampur (10.13 kattha), whereas the mean land holding under home garden was also higher in Dangibari (2.25 kattha ) followed by Dhaijan (2.12 kattha). The maximum land holding was 60 kattha whereas the minimum was found 0.5 kattha: moreover, the maximum land holdings under home garden were 8 kattha and minimum 0.2 kattha in the study area (Table 2). 
Table 2. Distribution of home garden practitioner based on land holdings in the study district

\begin{tabular}{lcccc}
\hline Name of VDCs & Mean & St. Deviation & Maximum & Minimum \\
\hline Dharampur & & & & 1 \\
Total own land (Kattha) & 10.13 & 1.81 & 6.0 & 0.2 \\
Home garden size (Kattha) & 1.64 & 15.35 & 60 & 0.5 \\
Dangibari & & 1.67 & 8.0 & 0.5 \\
Total own land (Kattha) & 23.61 & & & \\
Home garden size (Kattha) & 2.25 & 5.54 & 20.0 & 1.0 \\
Dhaijan & & 1.08 & 6.0 & 1.0 \\
Total own land (Kattha) & 7.15 & & & 0.5 \\
Home garden size (Kattha) & 2.06 & 13.04 & 60.0 & 0.2 \\
Total & & 1.32 & 8.0 & \\
Total own land (Kattha) & 13.63 & & & \\
Home garden size (Kattha) & 1.98 & & & \\
\hline
\end{tabular}

Source: Field survey, 2013

From this study it was evident that average home garden size was $14.52 \%$ of average total land holdings which is slightly higher than the findings of Gautam et al., 2004 i.e. $72 \%$ of households have home gardens of an area $2-11 \%$ of the total land holdings and smaller than the findings, it occupies 20\% of the total arable land (Jensen, 1993). The variation in such result may due to differential socioeconomic character.

\section{One-way ANNOVA analysis of socioeconomic characteristics and income distribution ofhome garden practitioners}

Different socio-economic parameters were analyzed among three VDCs using one way ANNOVA test. The variables such as total own land, area under home garden, total plant species, years of schooling, income from different components, annual household income were analyzed. Among the three VDCs total own land, total plant species, were found significant and others were not significant. The value from Duncan's test helps in the determination of homogeneity of the variables. Mean total own land was found 13.63 kattha and significant $(\mathrm{P}=0.01)$ among the VDCs, and on homogeneity test total own land of Dharampur and Dhaijan fall in same category, whereas total own land of Dangibari falls on other category. Mean of total plant species was found 42 and significant $(\mathrm{P}=0.5)$ among the VDCs. Further, on homogeneity test total plant species of Dangibari and Dhaijan fall under one category, whereas total plant species of Dharampur falls under another group. Although, there is variation of income across the VDCs, but was not significantly differ (Table $3)$.

Table 3. VDC wise socioeconomic characteristics and income distribution of home garden practitioner using one way ANNOVA

\begin{tabular}{lccccc}
\hline Variables & $\begin{array}{c}\text { Total } \\
\text { Average } \\
(\mathrm{N}=90)\end{array}$ & $\begin{array}{c}\text { Dharampur } \\
(\mathrm{n}=30)\end{array}$ & $\begin{array}{c}\text { Dangibari } \\
(\mathrm{n}=30)\end{array}$ & $\begin{array}{c}\text { Dhaijan } \\
(\mathrm{n}=30)\end{array}$ & F- value \\
& 13.6333 & $10.1333^{\mathrm{a}}$ & $23.6167^{\mathrm{b}}$ & $7.1500^{\mathrm{a}}$ & $19.100^{* * *}$ \\
\hline Total own land (kattha) & 1.98 & 1.642 & 2.250 & 2.067 & 1.678 \\
$\begin{array}{l}\text { Total own land under home garden } \\
\text { (kattha) }\end{array}$ & 42 & $47^{\mathrm{a}}$ & $45^{\mathrm{b}}$ & $34^{\mathrm{b}}$ & $3.55^{* *}$ \\
$\begin{array}{l}\text { Total plant species } \\
\text { Year of schooling }\end{array}$ & 7.04 & 7.4 & 7.4 & 6.26 & .931 \\
$\begin{array}{l}\text { Income from poultry component } \\
\text { (NRs) }\end{array}$ & 5465.9 & 6500 & 4850 & 4428.6 & .472
\end{tabular}




\begin{tabular}{|c|c|c|c|c|}
\hline $\begin{array}{l}\text { Income from fruit component } \\
\text { (NRs) }\end{array}$ & 4200 & 2370.6 & 3156.2 & 5907.1 \\
\hline $\begin{array}{l}\text { Income from livestock component } \\
\text { (NRs) }\end{array}$ & 21597 & 13260 & 22607 & 28270 \\
\hline $\begin{array}{l}\text { Income from other component } \\
\text { (NRs) }\end{array}$ & 8183.4 & 8370.6 & 13706 & 4115.5 \\
\hline $\begin{array}{l}\text { Income from vegetable component } \\
\text { (NRs) }\end{array}$ & 9873.3 & 7976.7 & 10115.4 & 11560 \\
\hline Home garden annual income (NRs) & 37697.24 & 29446.67 & 37278.36 & 46366.7 \\
\hline HH annual Income (NRs) & 195419.1 & 193579 & 169116.7 & 223500.0 \\
\hline
\end{tabular}

Source: Field survey, 2013

*** Significant at $1 \%$ level, ** significant at $5 \%$ level

\section{Home garden and its component contribution to income}

Contribution of home garden and its components on annual household income

As different components are integrated on home garden, its profitability in terms of income generation is worthwhile to be noted. In this perspectives attempt was made to identify the most profitable component. From the study it was evident that the home garden contribution on annual household income was $19.23 \%$ and livestock component was identified as most profitable component as it contributes $50.92 \%$ of home garden incomes followed by vegetable component (25.02\%) (Table 4).

Table 4. Contribution of home garden and its component on household income and home garden income

\begin{tabular}{|c|c|c|c|c|c|c|c|}
\hline \multirow[b]{2}{*}{ Particulars } & \multicolumn{7}{|c|}{ Annual income (NRs) } \\
\hline & Household & $\begin{array}{l}\text { Home } \\
\text { garden }\end{array}$ & Vegetable & Fruit & Livestock & Poultry & Other \\
\hline Mean & 196025.56 & 37697.20 & 9434.44 & 2846.60 & 19197.70 & 2672.22 & 3546.10 \\
\hline St. Dev. & 141182.24 & 35082.10 & 10737.80 & 5553.40 & 24927.40 & 5257.50 & 13682.10 \\
\hline $\begin{array}{l}\text { Percentage } \\
\text { contribution }\end{array}$ & & $19.23^{\#}$ & $25.02^{\# \#}$ & $7.55^{\# \#}$ & $50.92^{\# \#}$ & $7.08^{\# \#}$ & $9.40^{\# \#}$ \\
\hline
\end{tabular}

Source: Field survey, 2013

\# Home garden contribution on annual household income

\#\# Component contribution on home garden annual income

\section{Home garden and its contribution on household income}

The total annual household income; income from home garden and income from home garden components were analyzed in home garden practitioner and non practitioner household and mean was compared.

The total household income was found higher in-home garden practitioner compared to the non practitioner household but it was not statistically significant. It was found that the mean annual income from home garden was
NRs 37697.24 in practitioner household and significant $(\mathrm{P}=0.05)$. Among the home garden components the annual income was found highest in livestock component (NRs. 19197.77) followed by vegetable component (NRs. 9434.44). The annual income from home garden components such as vegetables, fruits and livestock components were found significant and higher in practitioner household whereas annual income from poultry and other component was not significant and higher in non practitioner household (Table 5). 
Table 5. Annual household incomes from different sources

\begin{tabular}{|c|c|c|c|c|}
\hline Annual $\mathrm{HH}$ income & $\begin{array}{c}\text { Home garden } \\
\text { practitioner }(n=90)\end{array}$ & $\begin{array}{l}\text { Non practitioner } \\
(\mathrm{n}=30)\end{array}$ & Mean Difference & t-value \\
\hline Total HH income (NRs.) & 196025.56 & 168873.33 & 27152.22 & 0.987 \\
\hline Home garden annual income (NRs) & 37697.24 & 19463.34 & $18233.91 * *$ & 2.593 \\
\hline $\begin{array}{l}\text { Annual home garden income from } \\
\text { vegetable (NRs) }\end{array}$ & 9434.44 & 2723.33 & $6711.11 * * *$ & 3.375 \\
\hline $\begin{array}{l}\text { Annual home garden income from fruit } \\
\text { (NRs) }\end{array}$ & 2846.66 & 1166.66 & $12297.77 *$ & 1.631 \\
\hline $\begin{array}{l}\text { Annual home garden income from } \\
\text { livestock (NRs) }\end{array}$ & 19197.77 & 6900.0 & $12297.77 * * *$ & 2.660 \\
\hline $\begin{array}{l}\text { Annual home garden income from } \\
\text { poultry component (NRs) }\end{array}$ & 2672.22 & 3033.33 & -361.11 & -0.289 \\
\hline Income from other component (NRs) & 3546.13 & 5640.0 & -2093.86 & -0.550 \\
\hline
\end{tabular}

Source: Field survey, 2013

*** Significant at $1 \%$ level, ** significant at $5 \%$ level, * significant at $10 \%$

Study revealed that home gardens adoption had positively contributed to income generation which is similar to the findings of Calvetet al. 2012 and Vassey, 1985 that is home garden contribute to income generation, improved livelihoods, and household economic welfare as well as promoting entrepreneurship and rural development.

\section{Sufficiency of home garden products on household requirement}

Home gardens, with their intensive and multiple uses, provide a safety net for households when food is scarce. To analyze duration of food supply by home garden, duration of time was categorized as year round, 9-12 months, 6-9 months, 3-6 months and 0-3 months. On

Table 16. Sufficiency of home garden components on household requirement

\begin{tabular}{|c|c|c|c|c|c|}
\hline \multirow{2}{*}{ Components } & \multicolumn{5}{|c|}{ Sufficiency } \\
\hline & Year round & 9-12 months & 6-9 months & 3-6 months & $0-3$ months \\
\hline Vegetable & $23(25.6)$ & $27(30.0)$ & $27(30.0)$ & $11(12.2)$ & $2(2.2)$ \\
\hline Fruit & $2(2.2)$ & $6(6.7)$ & $9(10.0)$ & $9(10.0)$ & $60(71.1)$ \\
\hline $\begin{array}{l}\text { Animal protein } \\
\text { requirement }\end{array}$ & $6(6.7)$ & $7(7.8)$ & $19(21.1)$ & $14(15.6)$ & $44(48.9)$ \\
\hline
\end{tabular}

Source Field survey, 2013

Figures in the parenthesis indicate percentage

From the study it was found that home garden plays important role on year round supply of food particularly vegetables which is consistent with the finding of (Budowski, 1990; Eiblet al., 2000). According to Budowski, 1990 and Eiblet al. 2000 home gardens are very important for supplying the household with food products year-round. study, $85.6 \%$ home garden practitioner responded that a vegetable produced under home garden was sufficient for more than 6 months. Furthermore, $71.1 \%$ and $48.9 \%$ respondent agreed that fruit produced under home garden and animal protein derived from home garden is sufficient for only 0-3 months. 
Dhaijan (2.12 kattha). From this study it was evident that average home garden size was $14.52 \%$ of average total land holdings. Mean total own land was found 13.63 kattha and significant $(\mathrm{P}=0.01)$ among the VDCs, and on homogeneity test total own land of Dharampur and Dhaijan fall in same category, whereas total own land of Dangibari falls on other category. Mean of total plant species was found 42 and significant $(\mathrm{P}=0.5)$ among the VDCs.From the study it was evident that the home garden contribution on annual household income was $19.23 \%$ and livestock component was identified as most profitable component as it contributes $50.92 \%$ of home garden incomes followed by vegetable component $(25.02 \%)$. The total household income was found higher in home garden practitioner compared to the non-practitioner household but it was not statistically significant. Mean annual income from home garden was NRs 37697.24 in practitioner household and significant $(\mathrm{P}=0.05)$. Home garden plays important role on year round supply of food particularly vegetables

\section{ACKNOWLEDGMENTS}

Authors are indebted to LiBIRD Nepal for providing partial financial support to undertake this research. The technical supports received from the officials of LiBIRD, Pokharaare highly acknowledged.

\section{AUTHORS' CONTRIBUTIONS}

B. Prasai conducted research and wrote the paper. D. Devkot, K.K. Pant, and R.H. Timilsina revised and finalized the paper.

\section{CONFLICT OF INTEREST}

The authors declare that there is no conflict of interest regarding publication of this manuscript.

\section{REFERENCES}

[1] Gautam, R., R. Suwal and P. K. Shrestha. 2004. Status of home gardens of Nepal: Findings of baseline survey conducted in four sites of home garden project. In: $\mathrm{R}$. Gautam, B. Sthapit and P. Shrestha (Eds.) Proceedings of national workshop (6-7 August). pp. 54-65.

[2] HKI. 2003. Integration of animal husbandry into home gardening programs to increase vitamin A intake from Region Office Asia-Pacific. Available at: http://www.hki. org/research/pdf-zipdocs/APRO\%20 Special\% 20 issue \%20Jan \%202003.pdf (Retrieved on February 15, 2013).

[3] HKI. 2003. Integration of animal husbandry into home gardening programs to increase vitamin A intake from Region Office Asia-Pacific. Available at: http://www.hki.
org/research/pdf-zipdocs/APRO\%20 Special\% 20 issue \%20Jan \%202003.pdf (Retrieved on February 15, 2013).

[4] Kimber, C. 1978. A folk context for plant domestication: or the dooryard garden revisited. Anthropological Journal of Canada 16 (4): 2-11.

[5] Kumar, B. M. and P. K. R. Nair. 2004. The enigma of tropical homegardens. Agroforestry Systems 61: 135-152.

[6] Miller, R. P. and P. K. R. Nair. 2006. Indigenous agroforestry systems in Amazonia: From

[7] Mitchell R. and T. Hanstad. 2004. Small home garden plots and sustainable livelihoods for the poor. Rural Development Institute (RDI), Livelihood Support Programme (LSP), FAO. pp. 1-43.

[8] MoAD. 2013. Statistical information on Nepalese agriculture. Ministry of Agriculture Development, Kathmandu.

[9] Ninez, V. 1987. Household gardens: Theoretical and policy considerations. Agricultural

[10] Shrestha, P., R. Gautam, R. B. Rana, and B. R. Sthapit. 2002. Home gardens in Nepal: Status and scope for research and development. In: J. W. Watson and P. B. Eyzaguirre. (Eds.). Home gardens and in- situ conservation of plant genetic resources in farming systems 17-19 July 2001. pp. 105-124. Germany/IPGRI, Rome.

[11] Smith, N. J. H. 1996. Home gardens as a springboard for agro forestry development in Amazonia. International Tree Crop Journal 9: 11-30.

[12] Soemarwoto, O. and G. R. Conway. 1992. The Javanese home garden. Journal for Farming Systems ResearchExtension 2: 95-118. 